\title{
Eleição do Novo Presidente do Grupo de Química Computacional
}

Na sequência da realização do 3. ${ }^{\circ}$ Simpósio de Química Computacional, que decorreu em simultâneo com o 14. ${ }^{\circ}$ Encontro de Química Física em formato digital entre 29 e 31 de março de 2021, o Grupo de Química Computacional (GQC) da Sociedade Portuguesa de Química reuniu para eleger os próximos presidentes do Grupo. Desta forma, durante o próximo mandato de dois anos, o presidente do GQC será o Prof. Doutor Alexandre Lopes de Magalhães, Professor Auxiliar da
FCUP, que sucede ao Prof. Doutor Daniel dos Santos, Investigador no LAQV-REQUIMTE também da FCUP. Quando terminar o seu mandato, este será substituído pelo Prof. Doutor Alfredo Palace Carvalho, Professor Auxiliar da Universidade de Évora.

Bruno Machado

brunofm@fe.up.pt

\section{Regulamento Sobre a Transparência da UE na Avaliação de Risco na Cadeia Alimentar Entrou em Vigor}

\begin{abstract}
A 27 de março de 2021 entrou em vigor o novo regulamento relativo à transparência e sustentabilidade do sistema da União Europeia de avaliação de risco na cadeia alimentar. Este regulamento, desenvolvido em resposta a uma iniciativa de Cidadania Europeia sobre pesticidas, visa garantir mais transparência na avaliação dos riscos na cadeia alimentar, aumentando a independência dos estudos desenvolvidos pela Autoridade Europeia para a Segurança dos Alimentos (EFSA), reforçando a governação e a cooperação científica da EFSA para garantir a sua sustentabilidade a longo prazo. Mais informação sobre o regulamento, objetivos e implementação pode ser encontrada em ec.europa. eu/food/safety/general_food_law/transparency-and-sustainability-eu-risk-assessment-food-chain.
\end{abstract}

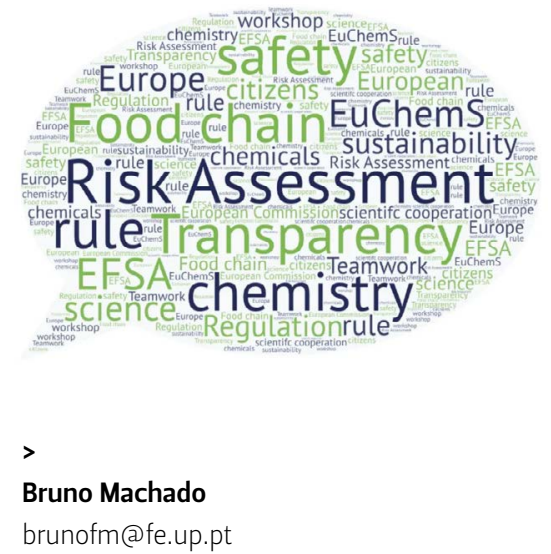

\section{Dióxido de Titânio: E171 Já Não é Considerado Seguro Quando Utilizado como Aditivo Alimentar}

\begin{abstract}
A Autoridade Europeia para a Segurança dos Alimentos (EFSA) publicou no passado dia 6 de maio de 2021 um estudo acerca dos riscos da toxicidade do dióxido de titânio. A Comissão Europeia solicitou esta avaliação em março de 2020, uma vez que a avaliação realizada em 2016 carecia de dados substanciais.

0 dióxido de titânio é um corante branco com uma vasta gama de aplicações, nomeadamente nas áreas da construção civil, cosmética e alimentar. $\mathrm{Na}$ indústria alimentar, este aditivo (E171) torna os alimentos visualmente mais atraentes, conferindo-Ihes
\end{abstract}

uma cor mais branca, com maior vivacidade e textura.

O principal risco destacado pela EFSA foi a genotoxicidade. Esta refere-se à capacidade de uma substância química de danificar o ADN, o material genético das células, que pode levar a problemas cancerígenos.

Cabe agora à Comissão Europeia e aos Estados Membros da UE incorporar os pareceres científicos da EFSA no seu próximo regulamento. 0 parecer da EFSA pode ser encontrado em EFSA Journal, 2021, 19, e06585. DOI: 10.2903/j.efsa.2021.6585. brunofm@fe.up.pt 